\title{
CHEMICAL STABILITY OF CEFTRIAXONE BY A VALIDATED STABILITY-INDICATING LIQUID CHROMATOGRAPHIC METHOD
}

\author{
M. DE DIEGO*, G. GODOY, S. MENNICKENT \\ University of Concepción, Pharmacy Department, Pharmacy School, PO Box 237, Concepción, Chile.
}

(Received: October 19, 2009 - Accepted: June 25, 2010)

\begin{abstract}
The chemical stability of ceftriaxone for injection reconstituted with water was studied at different storage conditions by a validated stability-indicating ion-pair liquid chromatographic method. The study was performed on ceftriaxone for injection samples obtained from two pharmaceutical laboratories, at three different temperatures: $23^{\circ} \mathrm{C} \pm 2{ }^{\circ} \mathrm{C},+8{ }^{\circ} \mathrm{C} \pm 1{ }^{\circ} \mathrm{C}$ and $-20^{\circ} \mathrm{C} \pm 0.5^{\circ} \mathrm{C}$, over 26 days, 55 days, and 76 days, respectively. Chromatographic separation was achieved on a RP-18 column, using a mobile phase consisting of $250 \mathrm{~mL}$ acetonitrile, $50 \mathrm{~mL}$ phosphate buffer ( $\mathrm{pH} 7.4 ; 0.1 \mathrm{M}), 3.2 \mathrm{~g}$ tetrabutylammonium bromide made up to a volume of $1 \mathrm{~L}$ with water, at a flow rate of $1.0 \mathrm{~mL} \mathrm{~min}^{-1}$ and UV detection at $260 \mathrm{~nm}$. The stability-indicating capability of the assay was established by forced degradation studies under hydrolysis, high temperature and photolysis. The developed method was specific, stability indicating, accurate and precise for ceftriaxone determination. At room temperature and at $+8{ }^{\circ} \mathrm{C}$ the degradation of ceftriaxone followed first-order kinetics and the samples were chemically stable for at least 4 and 41 days respectively. At $-20^{\circ} \mathrm{C}$ the concentration of all samples remained higher than $90 \%$ of the original concentration. Degradation of ceftriaxone was higher at room temperature; therefore lower storage temperatures improved the chemical stability of ceftriaxone for injection in water.
\end{abstract}

Keywords: Stability, ion-pair liquid chromatography, ceftriaxone.

\section{INTRODUCTION}

The stability of drug substances is defined as the extent to which a product retains, within specified limits, and throughout its period of storage and use, the same properties and characteristics that it possessed at the time of its manufacture ${ }^{1}$. These characteristics are related to chemical, physical, microbiological, therapeutic and toxicological specifications ${ }^{1,2}$. Chemical degradation of the active constituent often results in a loss in potency, or in a few instances the degradation products may be toxic ${ }^{2,3}$. When a pharmaceutical preparation is altered (e.g., by dissolution), or the storage conditions are modified, its stability may be affected ${ }^{4}$.

Cephalosporins are semisynyhetic $\beta$-lactam antibiotics. Ceftriaxone (Fig. 1 ) is a third generation cephalosporin antibiotic that has a broad antibacterial spectrum, and is used for the treatment of different infections ${ }^{5}$. b-lactam antibiotics undergo rapid ring opening due to hydrolysis, which results in a lower antimicrobial activity ${ }^{2,6}$, therefore it is very important the determination of ceftriaxone in pharmaceutical samples in order to ensure their stability. Ceftriaxone is commercially available as the disodium salt, ceftriaxone for injection must be reconstituted with sterile water for injection or parenteral solutions at the time of using, and this solution usually is administered by intravenous infusion or intramuscular injection. Since doses depend on the age of the patient and the disease, and ceftriaxone is the drug of choice for antiinfective therapy in the majority of paediatrics Chilean hospitals, generally only a portion of the constituted solution is used ${ }^{5}$. The portion which is not used is stored for the next administration or must be discarded because its stability is uncertain.<smiles>CO/N=C(\C(=O)N[C@H]1C(=O)N2C(C(=O)O)=C(CSc3nc(=O)c(O)nn3C)CS[C@H]12)c1csc(N)n1</smiles>

Fig. 1. Chemical structure of ceftriaxone.

In order to assess the stability of a compound, the methods used must be stability-indicating ${ }^{1}$. Several HPLC methods have been reported for the analysis of ceftriaxone in biological samples ${ }^{7-12}$. HPTLC $^{13}$, spectrophotometric ${ }^{14}$ and fluorimetric ${ }^{15}$ methods are described for determination in pharmaceutical samples. The official method for quantitative determination of ceftriaxone is ion-pair liquid chromatography with UV detection ${ }^{16}$. Also, there are few studies related with stability studies of ceftriaxone diluted with different solutions (sterile water, sodium chloride injection, dextrose injection, lidocaine hydrochloride injection) ${ }^{17-22}$. In these methods were not demonstrated the stability-indicating capability of the assay and/or were not sufficiently validated.

In order to determine the optimum storage conditions of two commercial ceftriaxone for injection commonly used in a local hospital, the objectives of this study were (1) to develop and validate a simple stability-indicating LC method for quantitative determination of ceftriaxone and (2) to determine the chemical stability of ceftriaxone for injection reconstituted with sterile water, at different storage conditions.

\section{EXPERIMENTAL}

\section{Chemicals and reagents}

Standard of Ceftriaxone sodium and cephradine were obtained from Sigma (St. Louis, MO, USA). Acetonitrile HPLC grade, tetrabutylammonium bromide, potassium dihydrogen phosphate and disodium hydrogen phosphate anhydrous p.a. grade were from Merck (Darmstadt, Germany). Ceftriaxone for injection containing $1 \mathrm{~g}$ ceftriaxone sodium was obtained from two Chilean pharmaceutical laboratories.

\section{Instrumentation}

The HPLC system consisted of a Perkin Elmer Series 200 liquid chromatograph (Norwalk, CT, USA) equipped with a manual injector, a 7125 Rheodyne injection valve (Cotati, CA, USA), and a $20-\mu \mathrm{L}$ loop. An Applied Biosystems Model 785A programmable absorbance detector (Foster, CA, USA), and a Perkin Elmer Nelson Model 1022 data processor (Norwalk, CT, USA).

Chromatographic conditions

All analyses were performed at temperature $23 \pm 2{ }^{\circ} \mathrm{C}$, under isocratic conditions. The chromatographic separation was carried out using a LiChrospher ${ }^{\circledR} \mathrm{RP}-18$ column (125 mm x $4 \mathrm{~mm}, 5 \mu \mathrm{m}$; Merck, Darmstadt, Germany). The mobile phase consisted of $250 \mathrm{~mL}$ acetonitrile, $50 \mathrm{~mL}$ phosphate buffer $(\mathrm{pH} 7.4 ; 0.1 \mathrm{M}), 3.2 \mathrm{~g}$ tetrabutylammonium bromide made up to a volume of $1 \mathrm{~L}$ with water (degassed and filtered through a $0.45-\mu \mathrm{m}, 47$ $\mathrm{mm}$ membrane filter under a negative pressure). The UV detection was made at $260 \mathrm{~nm}$ and the flow rate was $1.0 \mathrm{~mL} / \mathrm{min}$. Cephradine $(300 \mathrm{mg} / \mathrm{mL})$ was used as the internal standard.

\section{Preparation of solutions}

Stock and standard solutions

A stock solution of ceftriaxone and a stock solution of cephradine were independently prepared at about $1.0 \mathrm{mg} / \mathrm{mL}$ and $2.0 \mathrm{mg} / \mathrm{mL}$ respectively in water. Standard solutions were prepared from the stock solution after adequate 
dilution with water.

Sample preparation

Vials containing $1 \mathrm{~g}$ ceftriaxone sodium were reconstituted with $10 \mathrm{~mL}$ of sterile water (final concentration of $100 \mathrm{mg} / \mathrm{mL}$ ); these solutions were stored at the different conditions as indicated in section Stability studies. At the day of the measurement, $100 \mu \mathrm{L}$ of the $100 \mathrm{mg} / \mathrm{mL}$ ceftriaxone solution was transferred to a $5 \mathrm{~mL}$ volumetric flask and diluted with water to volume. Then, $200 \mu \mathrm{L}$ was transferred to a $2 \mathrm{~mL}$ volumetric flask and $300 \mu \mathrm{L}$ portion of internal standard $(2.0 \mathrm{mg} / \mathrm{mL}$ ) was added (final concentration of $300.0 \mathrm{mg} / \mathrm{mL}$ ), and diluted with water to volume (final concentration of ceftriaxone: $200.0 \mu \mathrm{g} / \mathrm{mL}$ ).

\section{Stability-indicating capability of the HPLC assay}

In order to determine if the method was stability-indicating, ceftriaxone was stressed under various conditions according to the ICH (international conference on harmonization) stability testing guidance ${ }^{23}$. For each condition, a blank solution was prepared and was subjected to stress in the same manner as the drug, also it was prepared a control solution, which was stored without the stress condition. Prior to analysis, samples were diluted to $200 \mu \mathrm{g} / \mathrm{mL}$.

Hydrolysis (acid and basic):

It was established by forced decomposition of $2.5 \mathrm{~mL}$ of an aqueous solution of ceftriaxone $1.0 \mathrm{mg} / \mathrm{mL}$ with $200 \mu \mathrm{L}$ of $0.1 \mathrm{~N}$ hydrochloric acid or $200 \mu \mathrm{L}$ of $0.1 \mathrm{~N}$ sodium hydroxide. The mixture was heated on a hot plate at $60{ }^{\circ} \mathrm{C}$ for 5 minutes, cooled to room temperature, and analyzed after dilution by the LC method.

\section{Temperature:}

An aqueous solution of ceftriaxone $1.0 \mathrm{mg} / \mathrm{mL}$ was exposed to dry heat $\left(60^{\circ} \mathrm{C}\right)$ in an oven for 5 hours.

Photostability:

An aqueous solution of ceftriaxone $1.0 \mathrm{mg} / \mathrm{mL}$ was exposed to UV and VIS radiation for 4 days. Dark controls were run simultaneously.

\section{Method validation}

The method was validated according to the ICH guidelines for validation of analytical procedures ${ }^{24}$. The parameters validated were linearity, precision, accuracy, selectivity, detection and quantitation limits.

\section{Stability studies}

The study was performed on ceftriaxone for injection obtained from two pharmaceutical laboratories. Samples were reconstituted with sterile water to a concentration of $100 \mathrm{mg} / \mathrm{mL}$ and then were stored at the following conditions: temperature $23 \pm 2{ }^{\circ} \mathrm{C}$ under presence and absence of light in a glass container for 26 days. $+8^{\circ} \mathrm{C} \pm 1{ }^{\circ} \mathrm{C}$ in a glass container for 55 days, and $-20^{\circ} \mathrm{C} \pm 0.5^{\circ} \mathrm{C}$ in a glass containers for 76 days.

At appropriate time intervals samples were taken and analyzed in duplicate by the LC method in order to determine the ceftriaxone concentration, after being thawed for $1 \mathrm{~h}$ at room temperature when they were maintained at $-20^{\circ} \mathrm{C}$ $\pm 0.5^{\circ} \mathrm{C}$, or after several minutes when they were stored at $+8^{\circ} \mathrm{C} \pm 1{ }^{\circ} \mathrm{C}$ (after sampling, they were discarded). Ceftriaxone samples were treated as indicated in section Sample preparation. Freshly-prepared internal standard was added to each sample immediately before analysis.

The percentage of ceftriaxone remaining after each time interval was determined by comparing the concentration at that time with the initial ceftriaxone concentration, measured before storage at the different conditions.

In order to determine the ceftriaxone degradation kinetics, graphs of the $\log \%$ residual versus time were plotted and the corresponding equations thus obtained.

Ceftriaxone was considered to be stable if the concentration was $\leq 90 \%$ of the initial concentration ${ }^{2}$.

\section{RESULTS AND DISCUSSION}

\section{Stability-indicating capability of the HPLC assay}

The main target of the stability-indicating chromatographic method is to get the separation between ceftriaxone and their degradation products. Acid and basic treatment of ceftriaxone, high temperature and UV and VIS radiation, resulted in a degradation product that eluted earlier $(2.4 \mathrm{~min})$ than ceftriaxone (5.6 $\mathrm{min})$. Also, treatment with base resulted in a degradation product that eluted later $(7.5 \mathrm{~min})$ than ceftriaxone. Fig. 2 shows a chromatogram of stressed sample, witch prove the stability-indicating capability of the assay.

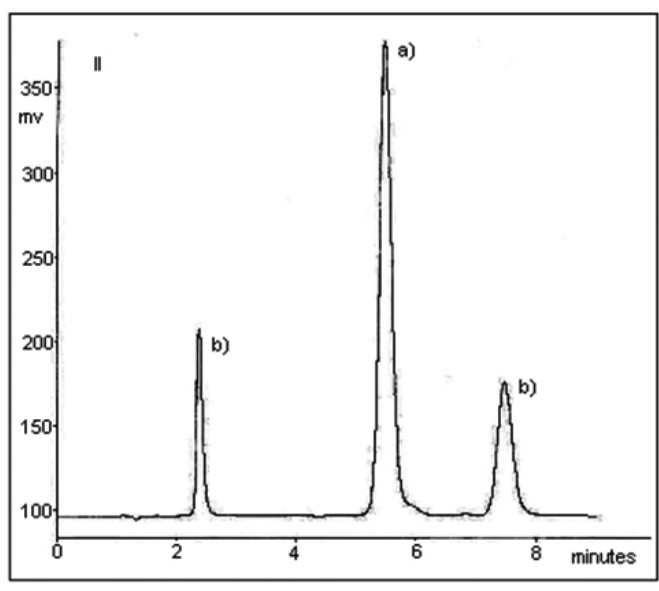

Fig. 2. Representative chromatogram of stressed sample: Ceftriaxone (a), degradation products (b).

\section{Method validation}

Linearity

The calibration curve of ceftriaxone was linear over the concentration range of 50.0 to $300.0 \mu \mathrm{g} / \mathrm{mL}$ (6 different concentrations were used and each solution was injected 5 times). The equation of the standard curve based on the ratio of the peak heights of ceftriaxone /internal standard to the ceftriaxone concentration was $y=0.0068-0.0279 ; \mathrm{r}^{2}=0.999$.

Precision

The intraday precision was evaluated by analysis of three different preparations in concentrations of $100.0,200.0$ and $300.0 \mu \mathrm{g} / \mathrm{mL}$ on the same day. The interday precision was studied by comparing the assays on three different days. The results are shown in Table 1. The precision is indicated in terms of RSD. The obtained values show a suitable precision for the analytical method.

Table 1. Precision of the method

\begin{tabular}{|c|c|c|}
\hline \multirow{2}{*}{$\begin{array}{c}\text { Concentration } \\
(\mu \mathrm{g} / \mathrm{mL})\end{array}$} & \multicolumn{2}{|c|}{ Relative standard deviation (\%) } \\
\cline { 2 - 3 } & intraday $^{\text {a) }}$ & interday $^{\mathrm{b})}$ \\
\hline 100.87 & 0.66 & 0.76 \\
\hline 201.74 & 1.60 & 2.66 \\
\hline 301.10 & 2.20 & 3.74 \\
\hline
\end{tabular}

a) Analyzed on the same day ( $\mathrm{n}=3$ ).

b) Analyzed on three different days $(\mathrm{n}=9)$.

\section{Accuracy}

To evaluate the accuracy of the method, recovery test were performed on three different preparations of ceftriaxone solutions in the concentration level 50,100 and $150 \%$ of the ceftriaxone levels for reconstituted samples (three replicates of each concentration). The accuracy of the assay was determined by comparing the found concentration with the added concentration. The results obtained are shown in Table 2. The obtained values confirm the accuracy of the proposed method.

Table 2. Method accuracy

\begin{tabular}{|cccc|}
\hline $\begin{array}{c}\text { Sample } \\
\text { Level }(\%)\end{array}$ & $\begin{array}{c}\text { Added Concentration } \\
(\mathrm{mg} / \mathrm{mL})\end{array}$ & $\begin{array}{c}\text { Found } \\
\text { Concentration } \\
(\mathrm{mg} / \mathrm{mL})^{\mathrm{a})}\end{array}$ & $\begin{array}{c}\text { Recovery } \\
(\%)^{\mathrm{b})}\end{array}$ \\
50 & 1.01 & $0.99 \pm 0.01$ & 98.15 \\
100 & 2.02 & $2.04 \pm 0.03$ & 100.98 \\
150 & 3.01 & $2.96 \pm 0.07$ & 98.44 \\
\hline
\end{tabular}

a) Mean $\pm \operatorname{SD}(\mathrm{n}=3)$.

b) (Found concentration/ Added concentration) x 100 . 
The selectivity was evaluated by observing any interference from excipients used in ceftriaxone for injection; therefore a sample of each commercial product of ceftriaxone for injection reconstituted in $10 \mathrm{~mL}$ of sterile water was analyzed without degradation, as shown in Fig. 3.

The selectivity was also studied by sample degradation, as explained in the stability-indicating capability of the HPLC assay shown in Fig. 2. These chromatograms showed no peaks that interfered with ceftriaxone or internal standard. These results proved the selectivity of the proposed method.

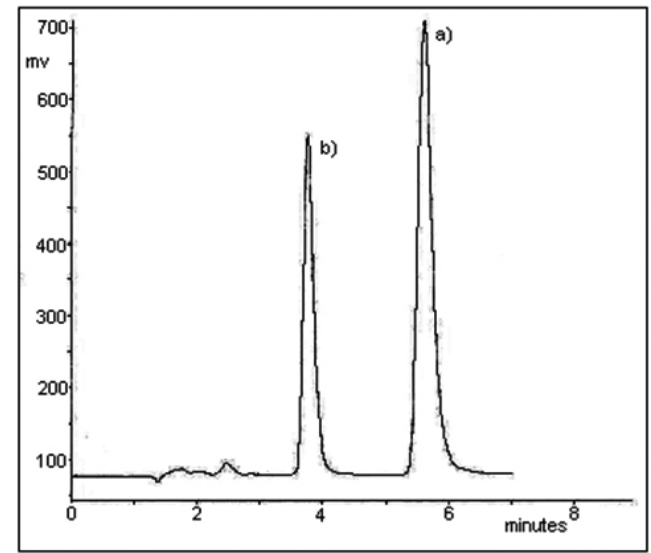

Fig. 3. Representative chromatogram of ceftriaxone for injection sample: ceftriaxone $200 \mathrm{mg} / \mathrm{mL}$ (a) and cephradine $300 \mathrm{mg} / \mathrm{mL}$ (b).

Detection and quantitation limits

The DL and QL were calculated by using the equations: $\mathrm{DL}=3.3 \mathrm{x} \mathrm{s} / \mathrm{S}$; $\mathrm{QL}=10 \mathrm{x} \mathrm{s} / \mathrm{S}$, where $\mathrm{s}$ is the standard deviation of the response and $\mathrm{S}$ is the slope of the calibration curve. Determined for three concentrations $(1.5,3.0$ and $4.5 \mu \mathrm{g} / \mathrm{mL})$. DL was $0.20 \mu \mathrm{g} / \mathrm{mL}$ and QL was $0.61 \mu \mathrm{g} / \mathrm{mL}$. These values are adequate for the detection and quantification of ceftriaxone in pharmaceutical samples.

\section{Stability studies}

The degradation of ceftriaxone for injection reconstituted with water at $100 \mathrm{mg} / \mathrm{mL}$ of two pharmaceutical laboratories, followed first-order kinetics at temperature $23 \pm 2{ }^{\circ} \mathrm{C}$ under presence and absence of light, and at $+8{ }^{\circ} \mathrm{C} \pm 1$ ${ }^{\circ} \mathrm{C}$. The degradation rate constants, the time at which concentration fell to $90 \%$ of the original concentration, and the determination coefficients are shown in Table 3.

Table 3. Degradation kinetics of ceftriaxone for injection

\begin{tabular}{|c|c|c|c|c|}
\hline $\begin{array}{l}\text { Pharmaceutical } \\
\text { laboratory }\end{array}$ & Storage condition & $\begin{array}{c}k^{\text {a) }} \\
\left(\text { Days }^{-1}\right)\end{array}$ & $\begin{array}{l}\left.t_{90}{ }^{b}\right) \\
\text { (Days) }\end{array}$ & $\mathrm{r}^{2 \mathrm{c})}$ \\
\hline \multirow[t]{3}{*}{ A } & $\begin{array}{l}23{ }^{\circ} \mathrm{C} \pm 2{ }^{\circ} \mathrm{C} \text { light } \\
\text { protection }\end{array}$ & 0.0214 & 4.92 & 0.9843 \\
\hline & $\begin{array}{c}23{ }^{\circ} \mathrm{C} \pm 2{ }^{\circ} \mathrm{C} \\
\text { light exposure }\end{array}$ & 0.0200 & 5.26 & 0.9850 \\
\hline & $+8^{\circ} \mathrm{C} \pm 1{ }^{\circ} \mathrm{C}$ & 0.0023 & 45.76 & 0.9234 \\
\hline \multirow[t]{3}{*}{ B } & $\begin{array}{l}23{ }^{\circ} \mathrm{C} \pm 2{ }^{\circ} \mathrm{C} \text { light } \\
\text { protection }\end{array}$ & 0.0198 & 5.32 & 0.9661 \\
\hline & $\begin{array}{c}23^{\circ} \mathrm{C} \pm 2{ }^{\circ} \mathrm{C} \\
\text { light exposure }\end{array}$ & 0.0200 & 5.26 & 0.9705 \\
\hline & $+8^{\circ} \mathrm{C} \pm 1{ }^{\circ} \mathrm{C}$ & 0.0025 & 41.60 & 0.9647 \\
\hline
\end{tabular}

a) Degradation rate constant

b) Time at which concentration fell to $90 \%$ of the original concentration

c) Determination coefficients
Ceftriaxone for injection reconstituted with water at $100 \mathrm{mg} / \mathrm{mL}$, of two pharmaceutical laboratories, when stored at $-20{ }^{\circ} \mathrm{C} \pm 0.5{ }^{\circ} \mathrm{C}$ retained at least $90 \%$ of the initial concentration over 76 days. The percentage of ceftriaxone remaining was $96.25 \%$ and 99.66 for each pharmaceutical laboratory respectively after 76 days.

\section{CONCLUSION}

A simple stability-indicating LC method to determine the chemical stability of ceftriaxone for injection has been developed and validated.

The results obtained from this study show that the stability of ceftriaxone for injection is higher at a lower temperatures. Ceftriaxone for injection of two pharmaceutical laboratories reconstituted with water to a concentration of 100 $\mathrm{mg} / \mathrm{mL}$, was chemically stable for at least 4 days when stored at temperature $23 \pm 2{ }^{\circ} \mathrm{C}$ under presence and absence of light; for at least 41 days at $+8^{\circ} \mathrm{C}$ $\pm 1{ }^{\circ} \mathrm{C}$; and for 76 days at $-20^{\circ} \mathrm{C} \pm 0.5^{\circ} \mathrm{C}$. Therefore could be stored in these conditions and used when needed, reducing waste and unnecessary expenses.

\section{ACKNOWLEDGEMENT}

This work was supported by research project DIUC 204.074.035-1.0, Research Department, University of Concepción.

\section{REFERENCES}

[1] Farmacopea de los Estados Unidos de América, 30 $0^{\text {th }}$ ed; United States Pharmacopeial Convection, Inc, Rockville, 2007; pp. 681.

[2] W. Lund. The Pharmaceutical Codex, $12^{\text {th }}$ ed. the Pharmaceutical Press, London, 1994; pp. 277-283.

[3] J. Carstensen, C. Rhodes. Drug Stability, Principles and Practices, $3^{\text {rd }}$ ed. Taylor \& Francis, New York, 2000; pp 3-7.

[4] K. Connors, G. Amidon, V. Stella. Chemical Stability of Pharmaceuticals, $2^{\text {nd }}$ ed. Edn. John Wiley \& Sons, New York, 1986; pp. 3.

[5] G. K. Mc Evoy. AHFS Drug Information. American Society of HealthSystem Pharmacists, Bethesda, 2006; pp. 154-170.

[6] S. Yoshioka, V. Stella. Stability of Drugs and Dosage Forms. Kluwer Academic Plenum Publishers, New York, 2000; pp. 11-12.

[7] S. Bompadre, L. Ferrante, L. Leone, J. Chromatogr. A. 812, 191, (1998)

[8] S. Kohlhepp, D. Gilbert, J. Leggett, Antimicrob. Agents Chemother. 42 , 2259, (1998)

[9] C. Hayward, A. Nafzinger, S. Kohlhepp, J. Bertino, Antimicrob. Agents Chemother. 40, 485, (1996)

[10] A. Kovar, T. Dalla Costa, H. Derendorf, J. Pharm. Sci. 86, 52, (1997)

[11] F. Péhourcq, C. Jarry, J. Chromatogr. A. 812, 159, (1998)

[12] S. Al-Rawithi, R. Hussein, D. Raines, I. Alshowaier, W. Kurdi, J. Pharm. Biomed. Anal. 22, 281, (2000)

[13] S. Eric-Jovanovic, D. Agbaba, D. Zivanov-Stakic, S. Vladimirov, J. Pharm.Biomed. Anal. 18, 893, (1998)

[14] K. Lakshmi, K. Ilango, Asian J. of Chem. 19, 2517, (2007)

[15] L. Bebawy, K. El Kelani, J. Pharm.Biomed. Anal. 32, 1219, (2003)

[16] Farmacopea de los Estados Unidos de América, 30 $30^{\text {th }}$ ed; United States Pharmacopeial Convection, Inc, Rockville, 2007; pp 1845-1847.

[17] Q. Xu, L. Trissel, C. Saenz, D. Ingram, K. Williams, J. Am. Pharm Assoc. 42: $428,(2002)$

[18] L. Bailey, K. Cappel, S. Orosz, Am. J. Hosp. Pharm. 51, 2159, (1994)

[19] L. Bailey, K. Tang, T. Medwick, Am. J. Hosp. Pharm. 50, 2092, (1993)

[20] M. De Diego, G. Godoy, R. Godoy, M. Maturana, J. Sep. Sci. 26, 939, (2003)

[21] R. Plumridge, A. Rieck, T. Annus, S. Langton, Am. J.Health Syst. Pharm. 53, 2323, (1996)

[22] R. Plumridge, A. Rieck, T. Annus, S. Langton, Am. J.Health Syst. Pharm. 53: 2320, (1996)

[23] International Conference on Harmonization, ICH Q1 A (R2), Stability Testing of New Drug Substances and Products, 2003.

[24] International Conference on Harmonization, ICH Q2B, Validation of Analytical Procedures, Methodology, 1996. 